\title{
Journal of the International AIDS

\section{Effects of NRTI backbone on HIV RNA, CD4 counts and lipids for first-line boosted PI-based HAART: meta-analysis of I 2 clinical trials in 4,896 patients}

\author{
AM Hill ${ }^{* 1}$ and WA Sawyer ${ }^{2}$
}

Address: ${ }^{1}$ Liverpool University, Liverpool, UK and ${ }^{2}$ SEARCH Thailand, Bangkok, Thailand

* Corresponding author

from Ninth International Congress on Drug Therapy in HIV Infection

Glasgow, UK. 9-13 November 2008

Published: 10 November 2008

Journal of the International AIDS Society 2008, I I (Suppl I):P5 doi:I0.I I86/I758-2652-I I-SI-P5

This abstract is available from: http://www.jiasociety.org/content/I I/SI/P5

(C) 2008 Hill and Sawyer; licensee BioMed Central Ltd.

\section{Background}

Several ritonavir-boosted PIs (PI/r) are currently recommended for use in first-line therapies for HIV infection. $\mathrm{TDF} / \mathrm{FTC}$ and $\mathrm{ABC} / 3 \mathrm{TC}$ are widely used with these PI/r, but there is conflicting evidence on their relative efficacy: the ACTG 5202 and BICOMBO trials suggest higher efficacy for TDF/FTC, whereas the HEAT trial shows no efficacy difference between the NRTI backbones.

\section{Methods}

A systematic MEDLINE search identified 21 treatment arms in 12 clinical trials of 4,896 antiretroviral naïve patients, where TDF/FTC $(\mathrm{n}=3,340)$ or ABC/3TC $(\mathrm{n}=$ $1,556)$ was the NRTI backbone used with PI/r. For each NRTI backbone and PI/r, the percent HIV RNA $<50$ copies $/ \mathrm{mL}$ at week 48 by standardised ITT TLOVR analysis were combined using inverse-variance weighting. The effect of baseline HIV-RNA, CD4 count and choice of NRTI backbone were examined using a weighted analysis of covariance. Changes in CD4 counts and lipids (TCHOL, TRIGS, HDL, LDL) were also assessed with the same methods.

\section{Summary of results}

For the TDF/FTC and ABC/3TC groups, there were no significant differences in median baseline CD4 (204 and 195, respectively) and mean log10 HIV-RNA (4.9 and 5.0, respectively). The efficacy of first-line HAART correlated with baseline HIV-RNA and CD4 count. Use of TDF/FTC was associated with higher rates of HIV-RNA suppression in each of the three third agents where data were available (LPV/r, fAPV/r and ATV/r). (Table 1.)

There was no difference in CD4 change to week 48 by type of PI or NRTI used. All lipid parameters showed significantly greater increases when $\mathrm{ABC} / 3 \mathrm{TC}$ was used, vs. TDF/ FTC. TCHOL and TRIGS showed significantly higher increases for LPV/r and fAPV/r, vs. ATV/r, SQV/r or DRV/r.

\section{Conclusion}

This systematic meta-analysis of standardised HIV-RNA $<50$ copy efficacy data at week 48 , using the FDA TLOVR algorithm, suggests higher efficacy for first-line use of a $\mathrm{TDF} / \mathrm{FTC}$ NRTI backbone, relative to use of $\mathrm{ABC} / 3 \mathrm{TC}$. However, CD4 increases were similar across the range of NRTIs and PIs used. Lipid profiles also differed by choice of NRTI backbone or boosted PI. 
Table I:

\begin{tabular}{|c|c|c|c|c|c|c|}
\hline NRTI backbone & TDF/FTC & & & ABC/3TC & & \\
\hline PI & $\mathbf{N}$ & RNA $<50$ & $95 \% \mathrm{Cl}$ & $\mathbf{N}$ & RNA $<50$ & $95 \% \mathrm{Cl}$ \\
\hline $\mathrm{LPV} / \mathrm{r}$ & 2285 & $74 \%$ & $72-76 \%$ & 722 & $66 \%$ & $63-70 \%$ \\
\hline$f A P V / r$ & 53 & $75 \%$ & $63-87 \%$ & 722 & $67 \%$ & $63-70 \%$ \\
\hline $\mathrm{ATV} / \mathrm{r}$ & 493 & $79 \%$ & $75-82 \%$ & 112 & $77 \%$ & $68-85 \%$ \\
\hline $\mathrm{SQV} / \mathrm{r}$ & 166 & $65 \%$ & $58-72 \%$ & no data & - & - \\
\hline $\mathrm{DRV} / \mathrm{r}$ & 343 & $84 \%$ & $80-88 \%$ & no data & - & - \\
\hline
\end{tabular}

Publish with Biomed Central and every scientist can read your work free of charge

"BioMed Central will be the most significant development for disseminating the results of biomedical research in our lifetime. "

Sir Paul Nurse, Cancer Research UK

Your research papers will be:

- available free of charge to the entire biomedical community

- peer reviewed and published immediately upon acceptance

- cited in PubMed and archived on PubMed Central

- yours - you keep the copyright

Submit your manuscript here:

http://www.biomedcentral.com/info/publishing_adv.asp 